\title{
MANAJEMEN RISIKO PEMBIAYAAN MUDHARABAH PADA PERBANKAN SYARIAH
}

\author{
Indrianawati, Nisful Lailah, Dewi Karina \\ Fakultas Ekonomi dan Bisnis Universitas Airlangga \\ E-mail: indrianawati@yahoo.com,nisful.laila@gmail.com, \\ dandewikarina91@gmail.com
}

\begin{abstract}
The purpose of this research is to determine risk management of mudharabah financing in Islamic banking limited to the causes of the low number of mudharabah financing, the common problems and solutions. The method of the research is using a qualitative approach with a case study strategy. The informants are obtained from 3 Islamic Banks (BUS), namely BMI, BSM and BNI Syariah. The data collection is conducted by combining the questions and the obtained data with the result of interview with the Account Officer from the 3 Islamic Banks; BMI, BSM, and BNI Syariah. The result of the research showed that the low number of mudharabah financing is caused by the massive risk, particularly the risk of losses on the bank income. Meanwhile, the problems that commonly occur are non-performing financing because of the side streaming and manipulated data. The solution is restructuring to the bank's customer who has a good faith. In contrast, bank's customers that have no good willing to fulfill their obligation will be put into the insurance execution.
\end{abstract}

Keywords: Mudharabah Financing, Risk Management, Side Streaming, Restructuring

\begin{abstract}
Abstrak
Tujuan dari penelitian ini adalah untuk mengetahui manajemen risiko pembiayaan mudharabah dalam perbankan Islam dengan batas penyebab rendahnya jumlah pembiayaan mudharabah, masalah umum dan solusi. Metode penelitian ini menggunakan pendekatan kualitatif dengan strategi studi kasus. Informasi diperoleh dari 3 Islami Bank atau Bank Umum Syariah (BUS), yaitu BMI, BSM dan BNI Syariah. Pengumpulan data dilakukan dengan menghubungkan pertanyaan dan data yang diperoleh dengan kesimpulan dari hasil data wawancara dengan Account Officer dari Bank Islam 3; BMI, BSM, dan BNI Syariah. Hasil penelitian menunjukkan bahwa rendahnya jumlah pembiayaan mudharabah disebabkan oleh risiko yang cukup besar, itu adalah risiko kerugian, terutama pada pendapatan bank. Sementara itu, masalah yang sering terjadi adalah non-performing pembiayaan karena streaming sisi dan data dimanipulasi. Solusinya adalah restrukturisasi kepada pelanggan bank yang memiliki itikad baik, sebaliknya, nasabah bank yang tidak memiliki baik bersedia memenuhi kewajiban mereka, akan dimasukkan ke dalam eksekusi jaminan.
\end{abstract}

Kata Kunci: Pembiayaan Mudharabah, Manajemen Risiko, Streaming Sisi, Restrukturisasi

Bank Syariah didirikan dengan tujuan untuk mempromosikan dan mengembangkan pe- nerapan prinsip-prinsip Islam dalam bidang muamalah ke dalam transaksi keuangan dan 
perbankan. Prinsip utama yang diikuti oleh bank syariah adalah larangan praktik riba dalam berbagai bentuk transaksi, melakukan kegiatan usaha dan perdagangan berdasarkan perolehan yang sah, dan upaya menyuburkan zakat sebagai alat distribusi kekayaan. Yahya (2011) menyatakan bahwa keharaman bunga dalam syariah membawa konsekuensi adanya penghapusan bunga secara mutlak. Teori Profit and Loss Sharing (PLS) dibangun sebagai tawaran baru di luar sistembunga yang cenderung tidak mencerminkan keadilan (injustice/dzalim) karena memberikan diskriminasi terhadap pembagian risiko maupun untung bagi para pelaku ekonomi. PLS merupakan kontrak bisnis dimana keuntungan dan/atau kerugian yang mungkin timbul dari kegiatan bisnis tersebut akan ditanggung bersama-sama.

Pembiayaan merupakan salah satu fungsi lembaga keuangan, khususnya bank syariah dengan cara menyalurkan dana dengan tujuan untuk memenuhi kebutuhan pihak yang kekurangan dana (deficit) untuk mendukung investasi yang telah direncanakan. Mudharabah adalah akad kerjasama usaha antara dua pihak dimana pihak pertama (shahibul maal) menyediakan seluruh modal (100\%), sedangkan pihak lainnya menjadi pengelola. Keuntungan usaha bersama dibagi menurut kesepakatan yang dituangkan dalam kontrak dalam bentuk nisbah bagi hasil. Sedangkan bila mendapat kerugian akan ditanggung oleh pemilik modal selama kerugian itu bukan akibat kelalaian si pengelola. Namun bila dia ikut punya andil dalamkerugian itu, maka dia wajib menanggungnya (Antonio 2001: 365).

Menurut Bank Indonesia dalam Laporan Perkembangan Perbankan Syariah sejak tahun 2009-2012, dilihat dari jenis akadnya, secara umum penyaluran pembiayaan perbankan syariah masih didominasi oleh akad murabahah (jual beli), sedangkan akad mudharabah masih menunjukkan porsi yang kecil. Secara teori seharusnya pembiayaan dengan sistem bagi hasil ini mengalami kenaikan, karena pada dasarnya pembiayaan inilah yang dianggap paling sesuai dengan semangat yang ada pada ekonomi Islam, di samping pembiayaan dengan sistem bagi hasil inilah yang memiliki potensi untuk dapat menghasilkan keuntungan tinggi bagi semua pihak.

Berdasarkan latar belakang tersebut di atas, penelitian ini bertujuan untuk menggali lebih dalam mengenai penyebab rendahnya jumlah pembiayaan mudharabah, permasalahan yang sering ditemui serta strategi penyelesaiannya pada perbankan syariah (Bank Muamalat Indonesia, Bank Syariah Mandiri, dan Bank BNI Syariah).

\section{Metode Penelitian}

Pendekatan yang digunakan dalam penelitian ini adalah pendekatan kualitatif dengan jenis penelitian studi kasus. Pendekatan kualitatif digunakan untuk menjawab pertanyaan penelitian tentang bagaimana manajemen risiko pembiayaan mudharabah pada perbankan syariah.

Data didapatkan dengan cara wawancara yang mendalam (indepth interview) kepada key informan. Key Informan berasal dari karyawan bank syariah, yang kesehariannya terlibat langsung dengan kegiatan pembiayaan produktif(mudharabah), dalam penelitian ini informan tersebut adalah Account Officer dari Bank Muamalat Indonesia, Bank Syariah Mandiri, dan Bank BNI Syariah.

Analisis data digunakan sebagai proses mencari dan menyusun secara sistematis data yang diperoleh dari hasil wawancara, observasi dan dokumentasi, dengan cara 
mengorganisasikan data ke dalam kategori, menjabarkan ke dalamunit-unit, melakukan sintesa, menyusun ke dalam pola, memilih mana yang penting dan yang akan dipelajari, dan membuat kesimpulan sehingga mudah dipahami oleh diri sendirimaupun orang lain (Sugiyono 2012: 244). Dalam penelitian ini analisis data dilakukan dengan menggunakan model Miles and Huberman, dengan tujuan agar bukti yang dikumpulkan dapat diperlakukan secara wajar, kemudian hasil yang didapat menghasilkan kesimpulan analisis yang mendukung, dan menetapkan alternatif interpretasi. Langkah analisis sebagai berikut: pertama, reduksi data. Data diperoleh dari hasil wawancara berupa rekaman wawancara, observasi, dan dokumentasi yang diperoleh dari Bank BMI, BSM, dan BNIS. Kemudian hasil wawancara dijabarkan ke dalam bentuk tulisan. Setelah mendapatkan datadata tersebut, peneliti melakukan pemilahan terhadap data-data tersebut. Peneliti hanya menyajikan data-data yang berhubungan dengan penelitian.

Kedua, penyajian data. Penyajian data merupakan sekumpulan informasi tersusun yang memberi kemungkinan untuk menarik kesimpulan dan pengambilan tindakan. Tujuannya adalah untuk memudahkan membaca dan menarik kesimpulan. Penelitimenyajikan data penelitian ini dalam bentuk teks naratif dan tabel.

Ketiga, penarikan kesimpulan. Pada tahap ini, peneliti membuat rumusan proposisi yang terkait dengan prinsip logika, mengangkatnya sebagai temuan penelitian, kemudian dilanjutkan dengan mengkaji secara berulangulang terhadap data yang ada, mengelompokkan data yang telah terbentuk dan proposisi yang telah dirumuskan.

Dalam penelitian ini, kebasahan data sebagai uji kredibilitas dilakukan peneliti dengan cara melakukan triangulasi. Sugiyono (2012: 273) menjelaskan bahwa triangulasi dalam pengujian kredibilitas ini diartikan sebagai pengecekan data dari berbagai sumber, dan berbagai cara/teknik. Tujuan dari teknik triangulasi ini adalah untuk menghilangkan perbedaan-perbedaan konstruksi kenyataan yang ada dalam konteks suatu studi sewaktu mengumpulkan data tentang berbagai kejadian dan hubungan dari berbagai pandangan. (Moleong 2009: 332). Triangulasi teknik dilakukan peneliti dengan cara mengecek data kepada sumber yang sama dengan teknik yang berbeda. Misalnya data diperoleh dengan wawancara, lalu dicek dengan observasi, dan dokumentasi. Selain itu, triangulasi juga dapat dilakukan peneliti dengan cara mengecek hasil penelitian dengan hasil penelitian dari peneliti lain yang melakukan pengumpulan data yang sama.

\section{Hasil Penelitian dan Pembahasan}

Uraian data penelitian ini meliputi tentang penjabaran data penelitian yang didapatkan dari hasil wawancara penelitian yang dilakukan kepada 5 orang yang bekerja sebagai Account Officer dari Bank BNI Syariah, Bank Muamalat Indonesia, dan Bank Syariah Mandiri. Uraian data penelitian ini disajikan dalam tabel 1 .

Tabel 1. Faktor Penyebab Rendahnya Pembiayaan Mudharabah

Bank BNI Syariah Bank Muamalat Indonesia Bank Syariah Mandiri

$\begin{array}{lll}\text { Risiko Besar } & \text { Risiko Besar } & \text { Risiko Besar }\end{array}$

Sumber: Wawancara Penelitian (diolah) 
Berdasarkan informasi pada tabel 1, dapat diketahui bahwasannya faktor penyebab mengapa jumlah pembiayaan mudharabah pada ketiga bank syariah berjumlah rendah, hal ini dikarenakan tingginya tingkat risiko yang akan ditanggung oleh bank syariah. Antonio (2001: 98), menyebutkan bahwa pada penerapan pembiayaan dengan akad al-mudharabah, memiliki risiko yang relatif tinggi. Jadi apa yang disampaikan para key informants tersebut mendukung apa yang disampaikan Antonio.

Berdasarkan informasi pada tabel 2, terlihat bahwasannya jenis risiko yang muncul pada pembiayaan mudharabah pada ketiga bank syariah di atas adalah tingginya pembiayaan macet yang disebabkan adanya side streaming, yaitu penyimpangan penggunaan dana oleh nasabah tidak sesuai dengan kesepakatan di awal akad, terjadinya perubahan manajemen kepengurusan nasabah, dan adanya ketidakjujuran nasabah (asymmetric information) saat melaporan kondisi keuangan usaha nasabah, sehingga pembiayaan yang disalurkan pada nasabah tidak sesuai dengan kemampuan yang dimiliki nasabah.

Pernyataan diatas mengkonfirmasi Antonio (2001: 98), tentang jenis-jenis risiko yang terjadi pada pembiayaan mudharabah. Salah satu jenis risiko pada pembiayaan mudharabah, adalah: Side streaming, di mana na- sabah menggunakan dana itu bukan seperti yang disebut dalamkontrak. Jenis risiko lainnya adalah lalai dan kesalahan yang disengaja, serta penyembunyian keuntungan oleh nasabah bila nasabahnya tidak jujur.

Berdasarkan informasi pada tabel 3, upaya penyelamatan pada ketiga bank syariah di atas adalah apabila kondisinasabah dilihat masih memilikiniat untuk mengembalikan dana pembiayaan pada bank syariah, maka dilakukan Restrukturisasi, yaitu reconditioning, rescheduling, atau restructuring. Sebaliknya, apabila kondisi nasabah sudah dilihat tidak memiliki niat untuk membayar angsuran pembiayaan, maka secara langsung bank syariah berhak menuntut atau mengeksekusi jaminan.

Ascarya (2007: 234) menyebutkan bahwa setiap bank wajib memiliki standar prosedur untuk menetapkan tindakan yang diambil dalam rangka rescheduling kewajiban yang belum terselesaikan, dalam hal pembiayaan bersifat revenue sharing. Dengan demikian pernyataan ketiga informan di atas mengkonfirmasi apa yang disampaikan oleh Ascarya.

Berdasarkan hasil pengamatan peneliti dilapangan dengan metode observasi yang secara langsung peneliti lakukan di Bank BNI Syariah sejak tanggal 2 Oktober 2013 hingga 1 November 2013, peneliti mendapatkan data adanya penyelesaian pembiayaan

Tabel 2. Jenis Risiko dalam Pembiayaan Mudharabah

\begin{tabular}{ccc}
\hline Bank BNI Syariah & Bank Muamalat Indonesia & Bank Syariah Mandiri \\
\hline Pembiayaan Macet, & $\begin{array}{c}\text { Pembiayaan Macet, karena side } \\
\text { karena Side Streaming } \\
\end{array}$ & $\begin{array}{c}\text { Pembiayaan Macet, } \\
\text { kepengurusan nasabah, serta } \\
\text { nasabah tidak jujur/manipulasi data } \\
\text { (asymmetric information) }\end{array}$ \\
&
\end{tabular}

Sumber: Wawancara Penelitian (diolah) 
bermasalah, hingga diadakannya Restrukturisasi oleh Bank BNI Syariah kepada nasabah tersebut, dengan cara memperpanjang jangka waktu angsuran dengan tujuan pembayaran angsuran oleh nasabah bisa lebih rendah. Sehingga hasil wawancara penelitian di atas sama dengan hasil dari pengamatan peneliti di lapangan.

Informasi dari ketiga Bank Syariah di atas, dapat dilihat bahwa kerugian berasal dari dua sumber, yaitu pertama, kerugian yang diakibatkan oleh kelalaian nasabah sehingga nasabahmasihmemilikikewajiban untuk membayar angsuran pembiayaan (nasabah yang menanggung kerugian). Kedua, kerugian karena benar-benar rugi di mana tidak adanya unsur kesengajaan darinasabah, misalkan na- sabah meninggal, maka asuransi yang mengcover kerugian tersebut (pihak ketiga yang menanggung kerugian). Ini dilakukan oleh bank sebagai pengamanan berlapis, dikarenakan amanah untuk mengelola dana masyarakat.

Investasi yang dijalankan melalui aktivitas pembiayaan merupakan aktivitas yang sering berkaitan dengan risiko, baik berkaitan dengan risiko nasabah (karakter) maupun dengan risiko proyek yang dibiayai tanpa terkecuali pada pembiayaan dengan akad mudharabah. Risiko yang sering muncul pada ketiga bank syariah di atas, baik pada BMI, BSM, dan BNI Syariah, dalam kegiatan pembiayaan mudharabah adalah risiko kerugian. Berdasarkan informasiseluruh informan, risiko kerugian yang dimaksud adalah tingginya

Tabel 3. Cara Penanganan Risiko dalam Pembiayaan Mudharabah

\begin{tabular}{|c|c|c|c|}
\hline & $\begin{array}{l}\text { Bank BNI } \\
\text { Syariah }\end{array}$ & $\begin{array}{l}\text { Bank Muamalat } \\
\text { Indonesia }\end{array}$ & $\begin{array}{c}\text { Bank Syariah } \\
\text { Mandiri }\end{array}$ \\
\hline $\begin{array}{l}\text { A. Saat } \\
\text { nasabah } \\
\text { mengalami } \\
\text { penurunan } \\
\text { kemampuan }\end{array}$ & $\begin{array}{c}\text { Dilakukan R3 } \\
\text { (Restruct } \\
\text { Recovery and } \\
\text { Remedial) dan } \\
\text { eksekusi jaminan. }\end{array}$ & $\begin{array}{l}\text { Divisi remedial } \\
\text { melakukan rekondisi, } \\
\text { reschedule, ataupun } \\
\text { restruktur dan } \\
\text { eksekusi jaminan. }\end{array}$ & $\begin{array}{c}\text { Diupayakan } \\
\text { rekondisi atau } \\
\text { restruktur dan } \\
\text { eksekusi jaminan. }\end{array}$ \\
\hline $\begin{array}{l}\text { B. Saat } \\
\text { kerugian benar- } \\
\text { benar terjadi }\end{array}$ & $\begin{array}{c}\text { Kerugian } \\
\text { ditanggung } \\
\text { nasabah } \\
\text { (mudharib) jika } \\
\text { disebabkan oleh } \\
\text { kelalaian } \\
\text { nasabah. Jika } \\
\text { sebaliknya, misal } \\
\text { force majeure } \\
\text { (nasabah } \\
\text { meninggal) } \\
\text { kerugian di cover } \\
\text { asuransi. }\end{array}$ & $\begin{array}{l}\text { Untuk mudharabah } \\
\text { dengan koperasi } \\
\text { sebagai nasabah, maka } \\
\text { kerugian akibat } \\
\text { penyimpangan } \\
\text { pengelola, pengelola } \\
\text { yang menanggung, } \\
\text { tapi jika sebab ruginya } \\
\text { karena anggota } \\
\text { (anggota meninggal) } \\
\text { sehingga koperasi } \\
\text { tidak bisa bayar, di } \\
\text { cover asuransi. }\end{array}$ & $\begin{array}{l}\text { Jika kerugian } \\
\text { berasal dari } \\
\text { nasabah yang tidak } \\
\text { bayar karena } \\
\text { meninggal, maka } \\
\text { akan tercover } \\
\text { asuransi, apabila } \\
\text { kerugian akibat } \\
\text { macet, terdapat } \\
\text { asuransi } \\
\text { penjaminan, maka } \\
\text { kerugian di } \\
\text { klaimkan kepada } \\
\text { pihak asuransi }\end{array}$ \\
\hline
\end{tabular}

Sumber: Wawancara Penelitian (diolah) 
rasio pembiayaan macet (Non Performing Financing/NPF). Penyebabnya adalah nasabah kehilangan kemampuan untuk membayar angsuran pembiayaan serta bagi hasil kepada bank sebagai pemilik modal dikarenakan nasabah melakukan kelalaian. Kelalaian yang dimaksud salah satunya adalah side streaming, di mana nasabah pembiayaan tidak memanfaatkan dana pembiayaan dengantepat, dan tidak sesuai dengantujuan pembiayaan yang diajukan sebelumnya. Selain itu, kelalaian lainnya sebagaimanayang telahdisampaikan oleh infoman BMI, adalah adanya ketidakjujuran nasabah (asymmetric information) dalam menyampaikan kondisi keuangan yang sebenarnya dari usaha yang akan dibiayai dengan memanipulasi data, sehingga menyebabkan analisa kemampuan nasabah tidak sesuai dengan kondisi sebenarnya di lapangan.

Berdasarkan teoritentang jenis-jenis risiko yang muncul pada kegiatan pembiayaan, informasi di atas sesuai dengan yang disampaikan oleh Ismail (2010: 123-124), bahwasannya tingkat risiko kerugian yang sering ditemui oleh bank adalah kredit bermasalah. Kredit bermasalah merupakan kredit yang telah disalurkan oleh bank, dan nasabah tidak dapat melakukan pembayaran atau melakukan angsuran sesuai dengan perjanjian yang telah ditandatangani oleh bank dan nasabah. Penyebabnya bisa karena faktor intern bank, seperti kesalahan dalam menganalisa usaha nasabah, bisa juga karena faktor ekstern bank, ini terjadi atas kesalahan yang dilakukan oleh nasabah itu sendiri, baik dengan unsur kesengajaan seperti penyelewengan dalam menggunakan dana kredit tidak sesuai dengan tujuan penggunaan (side streaming), ataupun unsur ketidaksengajaan seperti bencana alam yang menyebabkan kerugian oleh debitur.
Sebenarnya masalah seperti ini dapat dipecahkan dengan adanya nasabah yang amanah dan mampu memberikan gambaran nyata terhadap usaha yang akan dijalankan, dan mampu memberikan informasi yang tepat kepada Bank Syariah. Karena kedua masalah tersebut (side streaming dan asymmetric information) masih sering muncul, maka menjadi penyebab rendahnya pembiayaan dengan akad mudharabah.

Meskipun bank sudah melakukan analisis permohonan pembiayaan dengan cermat, risiko pembiayaan bermasalah masih mungkin terjadi. Tidak terdapat perbedaan yang signifikan dari ketiga bank syariah tersebut dalam melakukan penyelamatan pembiayaan yang bermasalah sebagai penyebab risiko kerugian yang akan ditanggung oleh bank. Informasi yang didapatkan dari seluruh informan diatas adalah jika nasabahdilihat masih memiliki niat untuk membayar, hanya saja sudah kehilangan kemampuan membayarnya, bank syariah dapat melakukan penyelesaian pembiayaan yaitu dengan cara Restrukturisasi kepada nasabah tersebut, yaitu dengan memperpanjang jangka waktu pembiayaan dengan menambah jumlah dana pembiayaan, atau memperpanjang waktu dengan membebaskan pembayaran bagi hasil yang tertunggak sebelumnya. Hal ini dilakukan oleh ketiga bank tersebut dengan harapan nasabah dapat melanjutkan usaha dengan kemudahan atau keringanan dalam melakukan pengembalian kepada pihak bank. Sebaliknya, apabila nasabah sudah tidak memilikiniat untuk menyelesaikannya, informasi dari seluruh informan adalah dengan segera pihak bank syariah secara langsung mengeksekusi jaminan..

Berdasarkan teori mengenai penyelesaian permasalahan untuk meminimalisir kerugian yang akan ditanggung oleh bank, 
informasi di atas sesuai dengan pendapat yang disampaikan oleh Laksmana (2009: 256), dimanaupaya yang bisa dilakukan oleh bank untuk penyelamatan terhadap pembiayaan bermasalah, adalah Rescheduling, Reconditioning, Restructuring. Ketiga upaya di atas bisa dilaksanakan oleh bank syariah hanya pada nasabah yang masih memiliki itikad baik akan tetapi telah kehilangan kemampuan membayar dikarenakan hal-hal yang tidak diinginkan. Dan sebaliknya apabila nasabah sudah tidak memiliki iktikad baik, maka alternatifterakhir yang dilakukan oleh bank adalah eksekusi agunan atau jaminan.

Jaminan dalam pembiayaan mudharabah pada ketiga bank syariah diatas seluruhnya tidak murnifix assets. Karena, penyaluran pembiayaan mudharabah pada ketiga bank diatas hanya disalurkan pada koperasi, BMT (baitul maal wa tamwil), serta multifinance (pada bank BMI). Pembiayaan dengan akad mudharabah itu hanya disalurkan pada koperasi dan sejenisnya sebagaimana disampaikan oleh informan BMI, ini dikarenakan pembiayaan dengan akad mudharabah memiliki risiko yang cukup besar, yaitu risiko kerugian, khususnya pada penghasilan yang akan diterima oleh bank, sehingga dikhususkan untuk koperasi dan sejenisnya karena bagi hasil yang diterima bank sudah jelas dan tetap (fix). Misalkan bank menyalurkan pembiayaan pada koperasi dengan nisbah bagi hasil 20:80, kemudian koperasi menyalurkan pembiayaannya ke anggota dengan pricing setara rate $15 \%$, maka dari sini bisa terlihat bahwa bank akan mendapatkan $20 \%$ dari $15 \%$ tersebut. Pembatasan penyaluran pembiayaan dengan akad mudharabah ini sendiri dikarenakan bank memiliki amanah dalam mengelola dana masyarakat (DPK) yang mana dalam hal ini bank juga memiliki amanah untuk mengembalikannya lengkap dengan bagihasilnya, jadibank dalam menyalurkan pembiayaan pasti akan melihat dari risiko usaha dan pengembalian pokok maupun hasilnya.

Pada prinsipnya dalam pembiayaan $m u$ dharabah, bank syariah tidak diwajibkan meminta agunan dari mudharib, namun untuk menciptakan saling percaya antara shahibul maal dan mudharib, maka shahibul maal diperbolehkan meminta jaminan. Jaminan diperlukan bila mudharib lalai dalam mengelola usaha atau sengaja melakukan pelanggaran terhadap perjanjian kerjasama yang telah disepakati. Jaminan ini digunakan untuk menutup kerugian atas kelalaian $m u$ dharib. Nasabah pembiayaan mudharabah pada BMI, BSM, dan BNI Syariah seluruhnya adalah koperasi karyawan atau BMT, khusus pada BMI terdapat nasabah multifinance, pengkhususan ini dikarenakan bagi hasil yang diterima bank sudah jelas dan tetap (fix) sejak dimulainya akad. Pada pembiayaan mudharabah ini pun juga terdapat adanya jaminan, akan tetapi jaminan yang serahkan pada bank bukan merupakan jaminan fix asset. Pada koperasi atau BMT, jaminan yang dipegang oleh bank adalah jaminan potong gaji dari anggota koperasi atau BMT, sedangkan pada multifinance yang dijaminkan adalah BPKB kendaraan yang dibeli oleh end usernya.

Informasi di atas sesuai Peraturan Bank Indonesia Nomor 7/46/PBI/2005 mengenai "Akad Penghimpunan dan Penyaluran Dana bagiBank yang Melaksanakan Kegiatan Usaha berdasarkan Prinsip Syariah", disebutkan bahwasannya bank syariah dapat meminta jaminan atau agunan untuk mengantisipasirisiko apabila nasabah tidak dapat memenuhi kewajiban sebagaimana dimuat dalam akad karena kelalaian dan/atau kecurangan. Selain itu, Karim (2004: 209) juga 
menjelaskan bahwa untuk menghindari adanya moral hazard dari pihak mudharib yang lalai atau menyalahi kontrak, maka shahibul maal dibolehkan meminta jaminan tertentu kepada mudharib. Jaminan ini akan disita oleh shahibul maal jika ternyata timbul kerugian karena mudharib melakukan kesalahan, yaknilalai atau ingkar janji. Apabila kerugian yang timbul disebabkan karena faktor risiko bisnis, jaminan mudharib tidak dapat disita oleh shahibul maal.

Adanya kerugian, merupakan dampak dari adanya wanprestasi yang dilakukan oleh nasabah pembiayaan, baik dilakukan tanpa adanya unsur kesengajaan ataupun sebaliknya. Tidak terkecuali pada perbankan syariah, dalam kegiatan pembiayaan mudharabah kadangkala wanprestasi sering muncul, dan rata-rata wanprestasi yang terjadi disebabkan adanya unsur kesalahan atau kelalaian dari nasabah itu sendiri sehingga menimbulkan kerugian bagibank yang bersangkutan. Menurut Informasi yang disampaikan seluruh informan dariketiga bank (BNI Syariah, BMI, dan BSM), kerugian yang terjadi pada pembiayaan mudharabah bisa disebabkan oleh kesalahan nasabah pembiayaan itu sendiri atau bisa juga bukan disebabkan oleh nasabah (risiko bisnis). Apabila kerugian disebabkan oleh kelalaian nasabah dimisalkan karena penyimpangan dana oleh pengurus yang mana dana dari bank tidak disalurkan pada anggotanya, jelas itu karena kesalahan nasabah, sehingga nasabah tetap memiliki kewajiban untuk membayar (nasabah yang menanggung kerugian), sedangkan apabila kerugian tersebut bukan dikarenakan kesalahan atau kelalaian nasabah, seperti misalkan nasabah tersebut meninggal sehingga tidak bisa membayar angsuran, dalam hal ini pembiayaan telah di-cover oleh asuransi. Sepertiinformasi yang dijelaskan sebelumnya, hal ini sengaja dilakukanolehbank syariah karena bank memiliki amanah untuk mengelola dana masyarakat atau DPK(Dana Pihak Ketiga), serta bank juga memiliki amanah penuh untuk dapat mengembalikan dana tersebut lengkap dengan bagi hasilnya.

Berdasarkan mengenaipihak siapa yang berhak bertanggung jawab jika terjadi kerugian dalam pembiyaan mudharabah, informasi diatas belum sesuai dengan teoriyang disampaikan oleh Ascarya (2007: 61), Ismail (2011: 171), Peraturan Bank Indonesia Nomor 7/46/PBI/ 2005, serta Hadits Thabrani, yang menyebutkan bahwasannya apabila terjadi kerugian karena proses normal dari usaha, dan bukan kelalaian atau kecurangan pengelola, kerugian ditanggung sepenuhnya oleh pemilik modal, dalam hal ini adalah bank syariah, sedangkan pengelola kehilangan tenaga dan keahlian yang telah dicurahkannya. Dan sebaliknya, apabila kerugian terjadi akibat dari kelalaian dan kecurangan pengelola, maka pengelola bertanggung jawab sepenuhnya.

Dari hasil pernyataan yang disebutkan oleh salah satu informan dari BMI, "kalo sebab ruginya karena anggota (biasanya anggota meninggal) sehingga koperasi gak bisa bayar itu dicover asuransi. Ini bukan perkara syariah atau engga, syariah jelas masih syariah selama ngga keluar dari rukun $m u$ dharabah, tapi kan bank punya amanah mengelola dana masyarakat (DP3) dan bank juga punya amanah mengembalikan dana tersebut dengan bagi hasilnya". Sedangkan teori sebelumnya menyebutkan bahwasannya "bank syariah lah yang menanggung seluruh risiko kerugian usaha yang dibiayai kecuali jika nasabah melakukan kecurangan, lalai, atau menyalahi perjanjian yang mengakibatkan kerugian usaha.

Terkait dengan dasar teori di atas mengenai pihak mana yang berhak bertanggung 
jawab atas adanya kerugian berdasarkan fakta di lapangan ternyata terdapat perbedaan dalam pengambilan keputusan saat kerugian murni bukan diakibatkan oleh kelalaian atau karakter buruk mudharib (risiko bisnis/force majeure), ketiga bank syariah, Bank Muamalat Indonesia, Bank Syariah Mandiri, dan Bank BNI Syariah, atau bahkan juga di bank syariah lainnya menerapkan hal yang sama, yaitu bank sebagai pengelola dana dari masyarakat (DPK) dengan sengaja memberi pengamanan berlapis pada dana masyarakat yang digunakan sebagai dana pembiayaan dengan melakukan kerjasama dengan pihak asuransi. Menurut seluruh informan dari ketiga bank syariah (BNI Syariah, BMI, dan BSM), hal ini sengaja dilakukan oleh bank syariah, karena bank syariah diberi amanah untuk mengelola dana masyarakat atau DPK (Dana Pihak Ketiga), serta bank juga memiliki amanah penuh untuk dapat mengembalikan dana tersebut lengkap dengan bagi hasilnya.

\section{Penutup}

Pertama, pada Laporan Keuangan baik pada BMI, BSM, maupun BNIS, aset yang dimiliki melalui pembiayaan mudharabah memiliki jumlah cukup rendah dibandingkan dengan pembiayaan murabahah, hal ini disebabkan karena penyaluran dana melalui pembiayaan mudharabah memiliki risiko yang cukup besar, yaitu pada risiko kerugian, khususnya pada penghasilan yang akan diterima oleh bank.

Kedua, risiko kerugian yang ditanggung oleh bank sebagai shahibul maal adalah tingginya jumlah pembiayaan bermasalah mulai dari kurang lancar bahkan macet. Penyebabnyaadalahhilangnyakemampuanuntuk membayar angsuran serta bagi hasil kepada bank dikarenakan nasabah melakukan kelalaian.
Kelalaiantersebut yaitu terjadinya side streaming, memanipulasi data (asymmetric information), sehingga menyebabkan kesalahan dalam menganalisa kemampuan nasabah.

Ketiga, upaya yang dilakukan bank dalam penyelamatan terhadap pembiayaan bermasalah, yaitu dengan cara Rescheduling, Reconditioning, Restructuring, ini dilakukan jika nasabah dianggap masih memiliki niat untuk membayar. Jika sebaliknya, dilakukan Eksekusi jaminan.

Keempat, kerugian yang muncul diakibatkan murni karena risiko bisnis bukan kelalaian nasabah (force majeure), baik pada BMI, BSM, ataupun BNIS, tidak secara langsung menanggung seluruh kerugian usaha yang dibiayai. Bank sengaja memberi pengamanan berlapis pada dana masyarakat yang digunakan sebagai dana pembiayaan dengan melakukan kerjasama dengan pihak asuransi untuk mengcover kerugian tersebut.

\section{DAFTAR PUSTAKA}

Antonio, Muhammad Syafi' i. 2001. Bank Syariah: dari Teori ke Praktek. Gema Insani Press.

Ascarya. 2007. Akad dan Produk Bank Syariah: Konsep dan Praktek di Beberapa Negara. Raja Grafindo Persada.

Bank BNI Syariah. (Online) (http:// www.bnisyariah.co.id), di akses 02 Desember 2013.

Bank Indonesia. 1998. UU RI No. 10 Tahun 1998 tentang Perubahan Atas UU No. 7 Tahun 1992 tentang Perbankan. 2008. UU RI No. 21 Tahun 2008 tentang Perbankan Syariah. 
Ekonomika-Bisnis Vol. 6 No.1 Bulan Januari Tahun 2015. Hal 55-66

2013. Laporan Perkembangan

Perbankan Syariah 2012.

Bank Muamalat. (Online) (http:// www.muamalatbank.com), diakses 02 Desember 2013.

Bank Syariah Mandiri. (Online) (http:// www.syariahmandiri.co.id), diakses 02 Desember 2013).

Bungin, Burhan. 2003. Analisis Data Penelitian Kualitatif. PT Raja Grafindo Persada.

Eick, Christine Louise Maney. 2003. Factors that Promote Effective Risk Management at Universities Classified by The Carnegie System As Doctoral/Research Universities-Extensive. Ann Arbor. ProQuest Information and Learning Company.

Fatwa Dewan Syariah Nasional: Pembiayaan Mudharabah (Qiradh). (Online) (http:/ /www.bapepam.go.id), di akses 27 September 2013.

Fuadi, Munir. 1996. Hukum Perbankan Modern (berdasarkan undangundang tahun 1998). PT CitraAditya Bhakti.

Ghufron, Mohammad AZ. 1999. Perlindungan Nasabah dalam Bank dengan Prinsip Syari' ah (studi tentang Bank Muamalat Indonesia). Jurnal Penelitian Universitas Merdeka Malang. LP Universitas Merdeka Malang.

Harwell, Rick. 2003. A Study of Effective Risk Management Practices in Higher Education. Ann Arbor: ProQuest Information and Learning Company.

Hendrie, MB Anto dan Desti Setyowati. 2008. The Indication of Moral Hazard in Financing: a Comparative Study between Islamic Bank and Conventional Bank in Indonesia. Dalam Mustafa Edwin Nasution (2007). Profit Sharing dan Moral Hazard dalam Penyaluran Dana Pihak Ketiga Bank Umum Syariah di Indonesia.

InfoBankNews: Misi Perbankan Syariah Bukan Cuma Soal Pangsa Pasar. (Online) (http://www.infobanknews.com), di akses 05 Desember 2013.

Ismail. 2010. Manajemen Perbankan. Kencana. Prenada Media Group.

-------. 2011. Perbankan Syariah. Kencana. Prenada Media Group.

Karim, A. Adiwarman. 2004. Bank Islam: Analisis Fiqih dan Keuangan. PT. Raja Grafindo Persada.

Laksmana, Yusak. 2009. Panduan Praktis Account Officer Bank Syariah: Memahami Praktik Proses Pembiayaan di Bank Syariah. PT. Elex Media Komputindo. Kompas Gramedia.

Moleong, Lexy J. 2009. Metode Penelitian Kualitatif. Bandung: PT. Remaja Rosdakarya.

Muhammad. 2005. Manajemen Dana Bank Syariah. Ekonisia.

Muchlis Yahya danEdy Yusuf Agunggunanto. 2011. Teori BagiHasil (Profit and Loss Sharing) dan Perbankan Syariah dalam Ekonomi Syariah. Jurnal Dinamika Ekonomi Pembangunan, Juli 2011, Volume 1, Nomor 1.

Nadeem U. Haque. 1986. Optimal Profitsharing Contracts and Investment in an Interest-Free Islamic Economy. International MonetaryFund. 
Manajemen Risiko Pembiayaan Mudharabah... (Indrianawati, Nisful L., Dewi K.)

Riyadi, Slamet. 2006. Banking, Assets, and Liability Management Edisi Ketiga. Jakarta: FakultasEkonomi Universitas Indonesia.

Sahrani, Sohari. 2011. Fikih Muamalah. Galia Indonesia.

Sarker, Md. Abdul Awwal. 1999. Islamic Business Contracts, Agency Problem and the Theory of the Islamic Firm. International Journal of Islamic Financial Services Vol. 1 No.2 July Sept. 1999.

Sugiyono. 2012. Metode Penelitian Kuantitatif, Kualitatif, dan $R \& D$. Alfabeta.

Yin, Robert K. 2009. Studi Kasus: Desain \& Metode. Rajawali Pers. Jakarta. 
